\title{
ANALISIS KETERKAITAN ANTAR KOMODITAS PROTEIN DENGAN MENGGUNAKAN MODEL ALMOST IDEAL DEMAND SYSTEM (AIDS)
}

\author{
CESA FEBRI DESTI, DODI DEVIANTO, IZZATI RAHMI HG \\ Program Studi Matematika, \\ Fakultas Matematika dan Ilmu Pengetahuan Alam, Universitas Andalas Padang, \\ Kampus UNAND Limau Manis Padang, Indonesia \\ cesafede@yahoo.com
}

\begin{abstract}
Abstrak. Penelitian ini bertujuan untuk melihat keterkaitan antar harga komoditas protein dengan menggunakan model Almost Ideal Demand System (AIDS).Objek penelitian adalah mahasiswa matematika Pasca Sarjana Universitas Andalas Padang yang mengkonsumsi komoditi sumber protein hewani meliputi : daging, ayam dan telur. Pendugaan parameter menggunakan metode Generalized Least Square (GLS) melalui persamaan Seemingly Unrelated Regression (SUR). Hasil penelitian menunjukkan proporsi konsumsi pangan yang dominan adalah komoditas ayam sebesar 0.409. Nilai elastisitas harga permintaan untuk ketiga komoditi memiliki tanda negatif, ini berarti bahwa ketiga komoditi merupakan kebutuhan pokok. Elastisitas pendapatan bertanda positif, mengindikasikan bahwa ketiga komoditi adalah barang normal. Pada umumnya elastistas harga silang bertanda positif, mengindikasikan bahwa antar komoditi pangan memiliki hubungan saling menggantikan.
\end{abstract}

Kata Kunci: Protein hewani, SUR, model Almost Ideal Demand System (AIDS).

\section{Pendahuluan}

Dalam upaya memperbaiki kehidupannya seseorang selalu berupaya untuk meningkatkan pendapatannya. Perubahan pendapatan ini akan mempengaruhi pola konsumsi pangan, termasuk pola konsumsi protein. Konsumsi protein untuk komoditas yang satu akan saling berkaitan dengan komoditas yang lain. Untuk membuat model yang mengambarkan fenomena tersebut diperlukan beberapa fungsi permintaan yang dipandang sebagai suatu sistem. Dalam penelitian ini akan digunakan Model Almost Ideal Demand System (AIDS). Adapun Penelitian ini bertujuan untuk melihat keterkaitan antar harga komoditas protein dengan menggunakan model Almost Ideal Demand System (AIDS).

\section{Model Almost Ideal Demand System (AIDS)}

Model Almost Ideal Demand System (AIDS) pertama kali diperkenalkan oleh Deaton dan Muellbauer pada tahun 1980. Model AIDS merupakan salah satu model yang mempelajari fungsi konsumsi dengan peubah sosial ekonomi, model ini merupakan pengembangan dari kurva Engel dan persamaan Marshallian yang diturunkan 
dari teori maksimasi kepuasan. Bentuk akhir dari model ini adalah:

$$
w_{i}=\alpha_{i}+\Sigma_{i} \gamma_{i j} \log p_{j}+\beta_{i} \log x / P,
$$

di mana :

$$
\begin{aligned}
i, j=1,2, \cdots, n, \\
w_{i}: \text { Proporsi pengeluaran untuk komoditas ke-i, } \\
p_{j}: \text { Harga agregat komoditas ke-j, } \\
\alpha_{i}, \gamma_{i j}, \beta_{i}: \text { Parameter model AIDS, } \\
P: \text { Indeks Stone, yaitu } \ln P=\Sigma_{i} w_{i} \log P_{i}, \\
x: \text { Total pengeluaran pangan hewani. }
\end{aligned}
$$

Model sistem permintaan di atas diduga dengan teknik Seemingly Unrelated Regression (SUR) dengan menggunakan bantuan perangkat lunak Statistical Analysis System (SAS).

\section{Metode Penelitian}

Penelitian ini merupakan studi kasus terhadap mahasiswa Pasca Sarjana Jurusan Matematika Universitas Andalas Padang. Data yang digunakan adalah data primer yang diperoleh dari wawancara dengan responden. Daftar pertanyaan meliputi kuantitas dan harga makanan yang dikonsumsi. Komoditas pangan yang disurvey adalah:

- Komoditi Daging.

- Komoditi Ayam.

- Telur.

Berdasarkan model AIDS di atas, diperoleh model sebagai berikut:

$$
\begin{aligned}
& w_{1}=\alpha_{1}+\gamma_{11} \log p_{1}+\gamma_{12} \log p_{2}+\gamma_{13} \log p_{3}+\beta_{1} \log (x / P)+\varepsilon_{1}, \\
& w_{2}=\alpha_{2}+\gamma_{21} \log p_{1}+\gamma_{22} \log p_{2}+\gamma_{23} \log p_{3}+\beta_{2} \log (x / P)+\varepsilon_{2}, \\
& w_{3}=\alpha_{3}+\gamma_{31} \log p_{1}+\gamma_{32} \log p_{2}+\gamma_{33} \log p_{3}+\beta_{3} \log (x / P)+\varepsilon_{3},
\end{aligned}
$$

di mana:

$w_{1}$ : Proporsi pengeluaran untuk komoditi daging berdasarkan model AIDS,

$w_{2}$ : Proporsi pengeluaran untuk komoditi ayam berdasarkan model AIDS,

$w_{3}$ : Proporsi pengeluaran untuk komoditi telur berdasarkan model AIDS,

$p_{1}$ : Harga komoditi daging (dalam Rupiah),

$p_{2}$ : Harga komoditi ayam (dalam Rupiah),

$p_{3}$ : Harga komoditi telur (dalam Rupiah),

$x$ : Total pengeluaran untuk komoditi daging, ayam dan telur,

$P$ : Indeks harga stone. 
Biasanya koefisien yang diperoleh diterjemahkan dalam bentuk elastisitas. Besarnya elastisitas permintaan untuk harga sendiri, harga silang dan pendapatan dapat diperoleh dengan rumus sebagai berikut:

(1) Elastisitas Harga Permintaan :

$$
\left(\left(\left(\gamma_{i i}-\beta_{i} w_{i}\right)\right) / W_{i}\right)-1
$$

(2) Elastisitas Harga Silang :

$$
\left(\left(\left(\gamma_{i j}-\beta_{i} w_{j}\right)\right) / W_{i}\right)
$$

(3) Elastisitas Pendapatan :

$$
\left(\beta_{i} / w_{i}\right)+1
$$

\section{Hasil dan Pembahasan}

\subsection{Gambaran umum data}

Proporsi dari pengeluaran untuk suatu komoditi tertentu dapat digunakan untuk mengetahui pola pengeluaran mahasiswa matematika pasca sarjana Universitas Andalas.

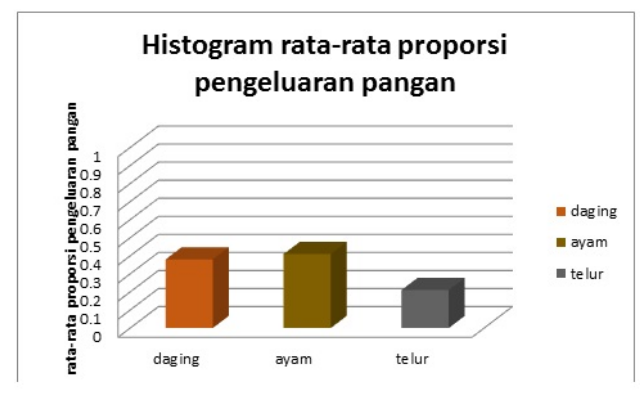

Gambar 4.1. Grafik proporsi pengeluaran pangan

Berdasarkan Gambar 4.1 terlihat bahwa kelompok makanan yang memiliki proporsi pengeluaran terbesar adalah komoditi ayam yaitu sebesar 0,409 yang diikuti dengan proporsi pengeluaran daging sebesar 0,380 dan terakhir proporsi pengeluaran terkecil adalah untuk komoditi telur yaitu sebanyak 0,210. Walaupun daging merupakan komoditi yang paling sedikit dikonsumsi, namun proporsi pengeluarannya tidak memiliki nilai paling kecil, ini disebabkan karena harga daging yang cukup tinggi, begitu juga dengan komoditi telur yang memiliki proporsi pengeluaran yang lebih kecil dari komoditi daging, padahal jumlah konsumsi telur lebih banyak dari konsumsi daging, ini disebabkan karena harga telur yang relatif jauh lebih murah dari daging. 


\subsection{Elastisitas Harga Permintaan}

Pada Gambar 4.2 berikut diberikan tabel elastisitas harga permintaan.

\begin{tabular}{|l|r|}
\hline \multicolumn{1}{|c|}{ Komoditas } & Elastisitas harga permintaan \\
\hline Daging & -5.826786656 \\
\hline Ayam & -4.475283101 \\
\hline Telur & -0.488230096 \\
\hline
\end{tabular}

Gambar 4.2. Tabel Elastisitas Harga Permintaan

Nilai elastisitas harga permintaan menunjukkan dampak perubahan harga komoditi yang bersangkutan terhadap tingkat konsumsi komoditi tersebut. Nilai elastisitas permintaan harga sendiri untuk ketiga komoditi memiliki tanda negatif, ini berarti apabila harga meningkat maka jumlah konsumsi terhadap ketiga komoditi tersebut akan menurun yang mengakibatkan pangsa pengeluaran untuk komoditi tersebut ikut turun.

Elastisitas harga permintaan untuk daging dan ayam bersifat elastis yang ditunjukkan oleh nilai absolut elastisitas yang lebih besar dari satu. Artinya persentase perubahan jumlah yang dikonsumsi sebagai respon dari perubahan harga lebih besar dari persentase perubahan harga. di mana dari hasil penelitian ini di dapat jika terjadi kenaikan harga daging sebesar 10 persen, akan terjadi penurunan pada jumlah konsumsi sebesar 58,26 persen dan jika terjadi kenaikan harga ayam sebesar 10 persen, akan terjadi penurunan jumlah konsumsi sebesar 44,75 persen.

Elastisitas harga permintaan untuk telur bersifat inelastis yang ditunjukkan oleh nilai absolut elastisitas harganya yang lebih kecil dari satu. Berarti persentase perubahan jumlah yang dikonsumsi sebagai respon dari perubahan harga, lebih kecil dari persentase perubahan harga. Jika harga telur mengalami kenaikan sebesar 10 persen, maka jumlah telur yang dikonsumsi akan turun sebesar 4.88 persen.

\subsection{Elastisitas Harga Silang}

Nilai elastisitas silang untuk masing-masing komoditi pangan hewani terhadap komiditi pangan hewani lainnya ditampilkan pada Gambar 4.3.

Dari Gambar 4.3 diketahui bahwa elastisitas harga silang ayam terhadap telur bertanda negatif. Hal ini menunjukkan adanya hubungan yang bersifat komplemen antara ayam dengan telur. Interpretasi dari hubungan komplemen antara ayam dengan telur ialah apabila terdapat penurunan harga telur, maka jumlah permintaan terhadap ayam akan meningkat.

Elastisitas harga silang daging terhadap ayam dan harga silang daging terhadap telur bertanda positif. Ini dapat diinterpretasikan dengan adanya hubungan substitusi antara daging dan ayam,begitupun dengan daging dan telur. 


\begin{tabular}{|l|c|c|c|}
\hline \multirow{2}{*}{ Harga } & \multicolumn{3}{|c|}{ Elastisitas Harga silang } \\
\cline { 2 - 4 } & Daging & Avam & Telur \\
\hline Daging & - & 4.263225644 & 0.392834653 \\
\hline Ayam & & - & -0.628195774 \\
\hline Telur & & & - \\
\hline
\end{tabular}

Gambar 4.3. Tabel Elastisitas Harga Silang

\subsection{Elastisitas Pendapatan}

Nilai elastisitas pendapatan dapat dilihat pada Gambar 4.4 berikut.

\begin{tabular}{|l|r|}
\hline \multicolumn{1}{|c|}{ Komoditas } & Elastisitas pendapatan \\
\hline Daging & 1.170731621 \\
\hline Ayam & 1.128276143 \\
\hline Telur & 0.442690506 \\
\hline
\end{tabular}

Gambar 4.4. Tabel Elastisitas Pendapatan

Elastisitas pendapatan pada ketiga komoditi mempunyai tanda positif. Hal ini menunjukkan bahwa ketiga komoditi merupakan barang normal, yaitu jika pendapatan konsumen meningkat, maka jumlah daging, ayam dan telur yang diminta juga akan meningkat.

\section{Daftar Pustaka}

[1] Deaton, Angus dan Muellbauer, John. 1980. An Almost Ideal Demand System. The American Economic Review. 70 (3) : 312 - 326

[2] Gilarso, T. 2007. Pengantar Ilmu Ekonomi Mikro. Yogyakarta:Kanisius

[3] Wardani, T.P.K. 2007. Analisis Pola Konsumsi dan Permintaan Buah Pada Tingkat Rumah Tangga di Pulau Jawa. http : //repository.ipb.ac.id/bitstream/ handle/123456789/44764/A07tpk.pdf? sequence $=1$ 